\title{
PENGEMBANGAN KUALITAS MEDIA PEMBELAJARAN TAJWID DI MI NU RAUDLATUL WILDAN DESA NGEMBALREJO KUDUS
}

\author{
Fifi Nofiaturrahmah \\ IAIN Kudus, Kudus, Indonesia \\ fifinofiaturrahmah@gmail.com \\ Salmah Fa'atin \\ IAIN Kudus, Kudus, Indonesia \\ salma@iainkudus.ac.id
}

\begin{abstract}
Abstrak
Madrasah Ibtidaiyah NU Raudlatul Wildan di Desa Ngembalrejo Kudus mengalami problem dalam pelaksanaan pembelajaran ilmu tajwid karena kendala media. Tujuan penelitian ini Guru di MI NU Raudlatul Wildan Kudus dapat mengembangkan pengetahuan mereka seputar media pembelajaran sehingga nantinya dapat dikembangkan media pembelajaran yang mempunyai konten sesuai dengan karakteristik guru dan sekolah. Guru mempunyai kemampuan di bidang pengembangan media. Adanya semangat untuk membuat sesuatu hal yang bersifat kreatif, sehingga pembelajaran tajwid tidak hanya dengan media whiteboard dan buku pegangan (handbook). Guru dapat menciptakan suasana belajar yang berbeda dan menyenangkan, sehingga peserta didik akan merasakan pengalaman yang berbeda dari model pembelajaran yang konvensional. Pelatihan pembuatan media pembelajaran tajwid science garden efektif dalam meningkatkan pemahaman materi hukum bacaan tajwid pada mata pelajaran Al-Qur'an hadits. Media pembelajaran tajwid science garden merupakan salah satu alternatif media pembelajaran yang dapat digunakan pada mata pelajaran Al-Qur'an hadits pada materi hukum bacaan tajwid yaitu hukum bacaan nun mati.
\end{abstract}

Kata Kunci : Kualitas Media Pembelajaran

\begin{abstract}
Madrasah Ibtidaiyah NU Raudlatul Wildan in Ngembalrejo Kudus village experienced problems in the implementation of learning recitation due to media constraints. The purpose of this study is that teachers in MI NU Raudlatul Wildan Kudus can develop their knowledge about learning media so that later learning media can be developed that have content in accordance with the characteristics of teachers and schools. The teacher has the ability in the field of media development. There is a spirit to make things creative, so learning Tajweed is not only with whiteboard media and handbooks. Teachers can create a different and pleasant learning atmosphere, so students will experience different experiences from conventional learning models. The training in making the medium of learning in the medium of science garden is effective in enhancing the understanding of tajwid reading law material in the subjects of the Qur'an hadith. The medium for learning the recitation of the science garden is an alternative learning media that can be used in the subjects of the Qur'an hadith in the legal material for recitation of recitation, namely the law of reading the dead.
\end{abstract}

Keywords: Quality of Learning Media 


\section{A. Pendahuluan}

Pada hakikatnya kegiatan belajar mengajar merupakan suatu proses komunikasi. Proses komunikasi (proses penyampaian pesan) harus diciptakan atau di wujudkan melalui kegiatan penyampaian dan tukar menukar informasi oleh setiap guru atau siswa. Yang di maksud informasi disini dapat berupa pengetahuan, keahlian, skill, ide, akal dan pengalaman, dan sebagainya. Melalui proses komunikasi, pesan atau informasi dapat dapat diserap dan dihayati orang lain. Agar tidak terjadi kesesatan dalam proses komunikasi perlu digunakan sarana yang membantu proses komunikasi yang disebut media (Ahmad Rohani , 1997 : 1-2).

Pengertian media dalam proses belajar mengajar cenderung diartikan sebagai alat-alat grafis, photografis, atau elektronis untuk menangkap, memproses, dan menyususn kembali informasi visual atau verbal. AECT (Association of Education and Communication Technology) memberi batasan tentang media sebagai segala bentuk dan saluran yang digunakan untuk menyampaikan pesan atau informasi. Selain sebagai sistem penyampai atau pengantar, media yang sering diganti dengan mediator menurut Fleming adalah penyebab atau alat yang turut campur tangan dalam dua pihak dan mendamaikannya (Ahmad Rohani , 1997 : 3).

Adanya media pembelajaran pada proses mengajar diharapkan dapat membantu guru dalam meningkatkan prestasi belajar pada siswanya. Oleh karena itu hendaknya menghadirkan media dalam setiap proses pembelajaran tersebut. Seringkali kata media pendidikan digunakan secara bergantian dengan istilah alat bantu aatu media komunikasi seperti yang dikemukakan oleh Oemar Hamalik dimana ia melihat bahwa hubungan komunikasi akan berjalan lancar dengan hassil yang maksimal apabila menggunakan alat bantu yang diseut media komunikasi (Azhar Arsyad : 4).

Media pembelajaran digunakan untuk meningkatkan mutu dalam proses kegiatan belajar mengajar. Media pembelajaran sangat membantu dalam upaya mencapai keberhasilan proses pendidikan dan pengajaran disekolah. Oleh sebab itu guru harus mempunyai keterampilan dalam memilih dan menggunakan media. Disamping itu, perlu dilakukan latihan praktek yang kontinyu dan sistematis (Ima Ratnasari, 2015).

Perkembangan ilmu pengetahuan dan teknologi semakin mendorong upaya-upaya pembaharuan dalam pemanfaatan hasil-hasil teknologi dalam proses 
belajar. Para guru dituntut agar mampu menggunakan alat-alat yang disediakan oleh sekolah, dan tidak menutup kemungkinan alat-alat tersebut sesuai dengan perkembangan dan tuntutan zaman. Guru sekurang-kurangnya dapat menggunakan alat yang murah dan efisien yang meskipun sederhana dan bersahaja tetapi menjadi keharusan dalam upaya mencapai tujuan pengajaran yang diharapkan. Disamping mampu menggunakan alat-alat yang tersedia, guru juga dituntut untuk dapat mengembangkan keterampilan membuat media pengajaran yang akan digunakannya apabila media tersebut belum tersedia. Untuk itu guru harus memiliki pengetahuan dan pemahaman yang cukup tentang media pembelajaran (Azhar Arsyad, 2006 :1-2).

Setiap media pembelajaran dapat digunakan untuk berbagai tujuan. Fungsi media pengajaran sangatlah besar, karena media pengajaran bisa menentukan berhasil tidaknya proses pengajaran dan merupakan bagian yang terpadu atau tidak dapat dipisahkan dalam sistem pengajaran. Media pengajaran tidak hanya sebagai alat untuk menyampaikan atau mentransfer informasi dan pengetahuan ke otak siswa, akan tetapi lebih dari itu media dapat dijadikan sebagai alat untuk mendorong siswa untuk memperoleh keterampilan-keterampilan, kebiasaan, bakat, minat, serta nilai-nilai yang diinginkan.

Mempelajari ilmu tajwid merupakan hal yang sangat penting bagi orang yang ingin mahir membaca apalagi menghafal Al-Qur'an. Seseorang yang paham dan fasih berbahasa Arab belum tentu bisa membaca Al-Qur'an kaidah tertentu, tata cara yang khusus, serta hanya di praktikkan terhadap kitab Allah yang mulia (AlQur'an) ( Ummi Chanifatin). Ilmu tajwid sangat bermanfaat bagi kaum muslimin, karena itu hukum mempelajarinya adalah fardlu kifayah yakni apabila sebagian kaum mukminin ada yang mempelajarinya, maka gugurlah kewajiban atas yang lain. Ilmu tajwid wajib diamalkan oleh setiap pembaca Al-Qur'an. Ia wajib membacanya (baik di dalam shalat maupun di luar shalat) dengan tartil (baik dan benar).

Hukum mengamalkan ilmu tajwid adalah fardlu 'ain, yakni wajib diamalkan bagi setiap muslim atau muslimah. Seseorang yang membaca Al-Qur'an dengan tanpa tajwid maka ia berdosa karena Allah SWT menurunkan Al-Qur'an dengan tartil dan tajwid (Thoha Husein, 2011 : 21-22).

Pada mata pelajaran Al-Qur'an Hadits dengan materi Tajwid media pembelajaran dapat dibuat sesuai dengan kebutuhan dan kreatifitas seorang siswa 
demi tercapainya pemahaman siswa terhadap materi pembelajaran yang telah disampaikan oleh pendidik. Sebagai mediator guru hendaknya memiliki pengetahuan dan pemahaman yang cukup tentang media media pendidikan, karena media pendidikan merupakan alat komunikasi guna lebih mengefektifkan proses belajar mengajar. Dengan demikian, jelaslah bahwa media pendidikan merupakan dasar yang sangat diperlukan yang bersifat melengkapi dan merupakan bagian integral demi berhasilnya proses pendidikan (Jumanta Hamdayana, 2016 : 11).

Mata pelajaran al-Qur'an Hadits khususnya di kelas I-VI salah satu materinya memuat tentang hukum-hukum bacaan tajwid. Jumlah siswa yang ada di MI NU Raudlatul Wildan sudah bisa dibilang banyak, dan tentunya dengan tingkat kualitas pemahaman yang berbeda-beda pula. Dalam memahami materi pelajaran tentu memerlukan perhatian dan konsentrasi penuh ketika prses belajar mengajar berlangsung. Untuk itu seorang pendidik harus pandai-pandai mencari perhatian siswa, dan membuat siswa lebih tertarik dengan pembelajaran di kelas, salah satunya yaitu dengan menggunakan media pembelajaran saat kegiatan belajar mengajar berlangsung.

Pada pendampingan ini akan memperkenalkan dan mengujicobakan media Tajwid Science Garden untuk mata pelajaran Al-Qur'an Hadits materi tajwid. Media Tajwid Science Garden ini merupakan media pembelajaran yang dibuat guna memfasilitasi kegiatan belajar mengajar mengajar pata materi bacaan ilmu tajwid. Media Tajwid Science Garden berarti media kebun ilmu tajwid. Media ini terbuat dari daur ulang barang-barang bekas. Media pembelajaran Tajwid Science Garden ini dibuat oleh pendamping sendiri dan belum pernah diterapkan dalam proses kegiatan belajar mengajar. Medianya berbentuk seperti pohon dengan cabangcabang ranting yang rantingnya itu berisi huruf-huruf dari bacaan ilmu tajwid yang akan diajarkan.

Media ini terdiri 3 bagian, yang pertama yaitu judul dari materi itu sendiri yang penulis buat menyerupai gerbang masuk sebuah kebun. Kemudian yang kedua yaitu tanaman-tanaman lengkap dengan ranting-ranting yang di tanam di pot, yang terdiri dari pot-pot. Dimana pot-pot itu berisi hukum bacaan tajwid. Dari media inilah diharapkan dapat membantu guru dalam mencapai tujuan pembelajaran.

Sugiarto menegaskan bahwa media pembelajaran adalah segala sesuatu yang digunakan orang utnuk menyampaikan pesan pembelajaran. Media pembelajaran 
yang baik harus memenuhi beberapa syarat, yaitu meningkatkan motivasi dan merangsang siswa untuk belajar, media dapat menjadikan siswa aktif dalam memberikan tanggapan, umpan balik dan mendorong siswa melakukan praktik yang benar (Tatang S , 2015 : 54). Selain itu syarat yang harus dipenuhi dalaam membuat media pembelajaran yaitu rasional (sesuai dengan akal dan mampu dipikirkan oleh penggunanaya), ilmiah (sesuai dengan kaidah-kaidah ilmu pengetahuan), ekonomis (sesuai dengan kemampuan pembiayaan sehingga lebih hemat dan efisien), praktis (dapat digunakan dalam kondisi praktis di sekolah dan bersifat sederhana) (Dina, 56).

\section{Fungsi dan Manfaat Media dalam Pendidikan}

Fungsi utama media pengajaran adalah sebagai alat bantu mengajar yang turut mempengaruhi iklim, kondisi dan lingkungan belajar yang ditata dan diciptakan oleh guru. Hamalik mengemukakan bahwa pemakaian media pengajaran dalam proses belajar mengajar dapat membangkitkan keinginan dan minat yang baru, membangkitkan motivasi dan rangsangan kegiatan belajar, dan bahkan membawa pengaruh-pengaruh psikologis terhadap siswa. Peggunaan media pengajaran pada tahap orientasi pengajaran akan sangat membantu keefektifan proses pembelajarandan penyampaian pesan dan isi pelajaran pada saat itu. Disamping membangkitkan motivasi dan minat siswa, media pengajaran juga dapat membantu siswa meningkatkan pemahaman, menyajikan data dengan menarik dan terpercaya, memudahkan penafsiran data, dan memadatkan informasi (Azhar Arsyad, 15-16).

Dalam proses pembelajaran, media memiliki fungsi sebagai pembawa informasi dari sumber (guru) menuju penerima (siswa). Dalam kegiatan interaksi antara siswa dan lingkungan, fungsi media dapat diketahui berdasarkan kelebihan media dan hambatan yang mungkin timbul dalam proses pembelajaran. Pengembangan media pembelajaran diupayakan untuk memanfaatkan kelebihan yang dimilikioleh media tersebut dan berusaha menghindari hambatan-hambatan yang mungkin muncul dalam proses pembelajaran (Tatang S, 57-58). Selain fungsi di atas, penggunaan media pembelajaran juga berfungsi sebagai berikut:

a) Fungsi Komunikatif.

Media pembelajaran digunakan untuk memudahkan komunikasi antara penyampai pesan dan penerima pesan. Kadang-kadang penyampaian pesan 
mengalami kesulitan manakala harus menyampaikan pesan dengan hanya mengandalkan bahasa verbal saja. Demikian juga penerima pesan, sering mengalami kesulitan saat menangkap materi yang disampaikan. Hususnya materi-materi yang bersifat abstrak.

b) Fungsi motivasi.

Dengan menggunakan media pembelajaran diharapkan siswa dapat lebih termotivasi dalam belajar.

c) Fungsi kebermaknaan.

Melalui penggunaan media, pembelajaran dapat lebih bermakna, yakni pembelajaran bukan hanya dapat meningkatkan pemahaman informasi berupa data dan fakta sebagai pengembangan aspek kognitif tahap rendah, akan tetapi dapat meningkatkan kemampuan siswa untuk menganalisis dan menciptakan sebagai aspek kognitif tahap tinggi.

d) Fungsi penyamaan persepsi

Walaupun pembelajaran di setting secara klasikal, namun pada kenyataannya proses belajar terjadi secara individual. Artinya bisa jadi setiap siswa akan menginterpretasi materi pelajaran secara berbeda. Melalui pemanfaatan media pembelajaran, diharapkan dapat menyamakan persepsi setiap siswa, sehingga setiap siswa memiliki pandangan yang sama terhadap informasi yang disuguhkan.

e) Fungsi individualitas.

Siswa datang dari latar belakang yang berbeda baik dilihat dari status sosial ekonomi maupun dari latar belakang pengalamannya, sehingga memungkinkan gaya dan kemampuan belajarnya pun tidak sama. Demikian juga halnya dengan bakat dan minat siswa tidak mungkin sama, walaupun secara fisik sama. Pemanfaatan media pembelajaran berfungsi untuk dapat melayani kebutuhan setiap individu yang memiliki minat dan gaya belajar yang berbeda( Wina Sanjaya, $2011: 73-75$ ).

Adapun manfaat media secara lebih husus, adalah sebagai berikut:

1) Penyampaian materi pelajaran dapat diseragamkan;

2) Proses pembelajaran menjadi lebih jelas, menarik dan interaktif;

3) Efisiensi dalam waktu dan tenaga;

4) Meningkatkan kualitas hasil belajar siswa; 
5) Memungkinkan proses belajar dapat dilakukan dimana saja dan kapan saja;

6) Menumbuhkan sikap positif terhadap materi dan proses belajar;

7) Mengubah peran guru kearah yang lebih posotif produktif;

8) Menambah gairah dan motivasi belajar siswa(Wina Sanjaya, $2011: 72$ ).

Dalam menggunakan media pendidikan sebagai alat komunikasi hususnya dalam hubungannya dengan masalah proses belajar mengajar, kiranya harus didasarkan pada kriteria pemilihan yang objektif. Sebab penggunaan media pendidikan tidak sekedar menampilkan program pengajaran kedalam kelas. Karena harus di kaitkan dengan tujuan pengajaran yang akan dicapai, strategi dikaitkan dengan tujuan pengajaran yang akan dicapai, strategi kegiatan belajar mengajar dan bahan.

Menurut Nana Sudjana dan Ahmad Rivai, ada beberapa hal yang perlu diperhatikan guru dalam menggunakan media pengajaran untuk mempertinggi kualitas pengajaran, diantaranya yaitu (Nana Sudjana dan Ahmad Rivai, 2009: 4):

a) Guru perlu memiliki pemahaman media pengajaran antara lain jenis dan manfaat media pengajaran, kriteria memilih dan mengajar dan tindak lanjut penggunaan media dalam proses belajar siswa;

b) Guru terampil membuat media pengajaran sederhana untuk keperluan pengajaran, terutama media dua dimensi atau media grafis, beberapa media tiga dimendi, dan edia proyeksi;

c) Pengetahuan dan keterampilan dalam menilai keefektifan penggunaan media dalam proses pengajaran. Menilai keefektifan media pengajaran penting bagi guru agar ia bisa menentukan apakah penggunaan media mutlak digunakan atau tidak selalu diperlukan dalam pengajaran sehubungan dengan prestasi belajar yang dicapapi siswa. apabila penggunaan media pengajaran tidak mempengaruhi proses dan kualitas pengajaran, sebaiknya guru tidak memaksakan penggunaannya, dan perlu mencari usaha lain di luar media pembelajaran.

\section{Media Tajwid Science Garden}

Seperti yang telah pendamping jelaskan di atas, media merupakan alat bantu yang digunakan dalam kegiatan belajar mengajar, agar suatu tujuan pembelajaran dapat tercapai. Sedangkan media Tajwid Science Garden berarti 
kebun ilmu tajwid, alat bantu yang di buat menyerupai kebun. Dinamakan kebun karena terdiri dari pohon-pohon. Pohon-pohon itu berisi hukum-hukum bacaan ilmu tajwid, dimana akan membantu siswa dalam memahami materi mengenai hukum bacaan yang terdapat dalam ilmu tajwid.

Media Tajwid Science Garden ini merupakan salah satu media yang membantu siswa untuk memahami materi pembelajaran tajwid hususnya pada materi hukum bacaan ilmu tajwid. Dengan menggunakan media ini diharapkan siswa mempunyai kesan tersendiri, yaitu materi pelajaran yang disampaikan oleh guru tetap diingat oleh siswa. Namun penggunaan media pembelajaran tidaklah selalu efektif, tergantung pada bagaimana caranya seorang guru dapat mengendalikan serta menguasai keadaan siswa serta tergantung pula bagaimana caranya mengelola media tersebut dan menyampaikannya kepada siswa. Karena belajar mengingat itu tidaklah mudah.

Dalam pendampingan ini, pendamping menggunakan media Tajwid Science Garden tidak pada semua materi, namun di batasi hanya untuk materi tentang hukum bacaan nun mati dan mim mati saja. Karena dalam bacaan hukum mim mati sudah terdapat tiga jenis hukum bacaan mim mati yaitu Idgham Mimi, Ikhfa 'Syafawi, dan Izhar Syafawi. Sedangkan pada bacaan hukum nun mati terdapa lima macam hukum bacaan tajwid yaitu Izhar Halqi, Idgham Bigunnah, Idgham Bilagunnah, Iqlab, dan Ikhfa' Hakiki. Dari kedelapan hukum bacaan tajwid tersebut, pendamping rasa sudah cukup untuk dijadikan sebagai materi dalam pelaksaan penerapan media Tajwid Science Garden di Madrasah .

Pemahaman (comprehension) yaitu jenjang kemampuan yang menuntun siswa untuk memahami atau mengerti tentang materi pelajaran yang disampaikan guru dan dapat memanfaatkannya tanpa harus menghubungkannya dengan hal-hal lain. Kemampuan ini dijabarkan menjadi tiga yaitu, menterjemahkan, menafsirkan dan mengekstrapolasi (Zainal Arifin, 2012 : 48). Adapun pemahaman menerjemahkan yaitu kesanggupan untuk menjelaskan makna yang terkandung di dalam sesuatu, contonya menerjemahkan kalimat, sandi dan lain sebagainya. Pemahaman menafsirkan sesuatu contohnya menafsirkan grafik, sedangkan pemahaman ekstrapolasi yakni kemampuan untuk melihat dibalik yang tersirat atau tersurat. 
Siswa dikatakan memahami bila mereka dapat mengkonstruksi makna dari pesan-pesan pembelajaran, baik yang bersifat lisan, tulisan ataupun grafis, yang disampaikan melalui pengajaran, buku, ataupun layar komputer (Wina Sanjaya, 2011 : 102). Setiap murid harus mempunyai kesanggupan untuk memahami pengajaran. Kalau murud tidak dapat memahami apa yang dikatakan atau yang disampaikan oleh guru, atau bila guru tidak dapat berkomunikasi dengan murid, maka besar kemungkinan murid tidak dapat menguasai mata pelajaran yang diajarkan oleh guru itu. Kemampuan murid untuk menguasai suatu bidang studi banyak bergantung pada kemampuannya untuk memahami ucapan guru. Sebaliknya guru yang tidak sanggup menyatakan buah pikirannya dengan jelas sehingga ia dipahami oleh murid, juga tidak dapat mencapai penguasaan penuh oleh murid atas bahan pelajaran yang disampaikannya.

Dalam pengajaran seperti yang terdapat di sekolah-sekolah, banyak digunakan komunikasi verbal. Guru menyampaikan bahan pelajaran melalui bahasa. Penggunaan alat peraga atau alat audio-visual, film, film strip, model, dan sebagainya sangat minimal (S. Nasution, 42-44). Pemahaman lebih tinggi tingkatannya dari pada pengetahuan. Pemahaman bukan hanya sekedar mengingat fakta, akan tetapi berkenaan dengan kemampuan menjelaskanmenerangkan, menafsirkan, atau kemampuan menangkap makna atau arti suatu konsep (Wina Sanjaya, 2011 : 102).

\section{Hukum Bacaan Ilmu Tajwid}

\section{a) Definisi ilmu tajwid}

Tajwid menurut etimologi berarti tahsin, yang berarti memperbaiki atau memperbagus. Oleh karena itu ungkapan jawwada Al-Qur'ani mempunyai arti hassana tilawati Al-Qur'ani (memperbaiki atau memperbagus bacaan Al-Qur'an). Sedangkan secara terminologi ulama qurra' (ahli Al-Qur'an) berarti mengucapkan setiap huruf dari makhrajnya secara benar dengan menunaikan seluruh haknya yakni sifat absolute huruf yang selalu menempel padanya (misalnya hams, jahr, isti'la', gunnah, dan lain-lain) dan menunaikan seluruh mustahak nya yakni sifat kondisional huruf yang sewaktu-waktu atau dalam kondisi tertentu ada padanya (misal tafhim, tarqiq, isymam, saktah, izhar, idgam, iqlaab, ihfak, dan lain-lain) (Achmad Thoha Husein Al-Mujahid : 20). 
Seseorang yang membaca Al-Qur'an, baik tanpa lagu maupun dilagukan dengan indah dan merdu, tidak boleh terlepas dari kaidah-kaidah tajwid. Tajwid merupakan bentuk masdar dari fi'il madhi jawwada yang berarti membaguskan, menyempurnakan, memantapkan. Kemudian pendapat yang lain tentang pengertian ilmu tajwid yaitu ilmu yang berguna untuk mengetahui bagaimana cara memenuhkan/memberikan hak huruf dan mustahaqnya. Baik yang berkaitan dengan sifat, mad, dan sebagainya seperti tarqiq dan tafhim dan selain keduanya (Ahmad Annuri, 2010 : 17)

Adapun ruang lingkup ilmu tajwidsecara garis besar dapat dibagi menjadi dua bagian yaitu:

1) Haqqul Harf, yaitu segala sesuatu yang wajib ada pada setiap huruf. Hak huruf meliputi sifat-sifat huruf (shifatul harf) dan tempat-tempat keluarnya huruf (makharijul harf). Apabila hak huruf ditiadakan, maka semua suara yang diucapkan tidak mungkin mengandung makna karena bunyinya menjadi tidak jelas. Begitu pun lambang suara tidak mungkin diwujudkan dalam bentuk lisan.

2) Mustaḥaqqul harf, yaitu hukum-hukum baru yang timbul oleh sebebsebab tertentu setelah hak-hak huruf melekat pada setiap huruf. Hukumhukum ini berguna untuk menjaga hak-hak huruf tersebut, makna-makna yang terkandung di dalamnya serta makna-makna yang dikehendaki oleh setiap rangkaian huruf. Mustahiqqul harf meliputi hukum-hukum seperti iẓhar, ihfa', iqlab, idgam, qalqalah, gunnah, tafhim, tarqiq, madd, waqaf, dan lain-lain (Acep Lim Abdurohim : 4-5).

\section{b) Dasar Hukum Ilmu Tajwid}

Ilmu tajwid wajib diamalkan oleh setiap pembaca Al-Qur'an. Ia wajib membacanya (baik didalam shalat maupun diluar shalat) dengan tartil (baik dan benar). Pada suatu hari sahabat Ali Bin Abu Thalib bertanya tentang arti tartil kemudian Rasulullah menjawab:

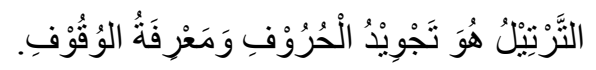

Artinya: "Tartil ialah membaguskan huruf-hurufnya dan mengetahui tempat-tempat berhentinya”. ( Ahmad Annuri : 18).

Hukum mengamalkan ilmu tajwid adalah farḍu 'ain, yakni wajib diamalkan bagi setiap muslim atau muslimah. Seseorang yang membaca Al- 
Qur'an dengan tanpa tajwid maka ia berdosa karena Allah SAW menurunkan Al-Qur'an dengan tartil dan tajwid (Acmad Thoha Husein AlMujahid : 22). Sebagaimana diketahui pada uraian dibawah ini:

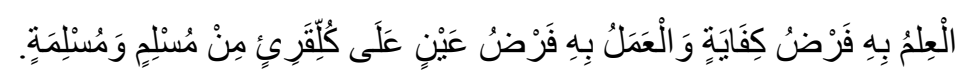

Artinya:"Mempelajari ilmu tajwid (hukumnya) fardlu kifayah dan mengamalkannya fardlu 'ain bagi setap pembaca Al-Qur'an (qari') dari umat Islam (laki-laki dan perempuan)"( Ahmad Annuri : 17).

Pada uraian di atas dijelaskan bahwasannya hukum mempelajari ilmu tajwis sebagai disiplin ilmu adalah farḍ kifayah atau merupakan kewajiban kolektif. Ini artinya, mempelajari ilmu tajwid secara mendalam tidak diharuskan bagi setiap orang, tetapi cukup diwakili oleh beberapa orang saja. Namun, jika dalam satu kaum tidak ada seorang pun yang mempelajari ilmu tajwid, maka berdosalah kaum tersebut. Adapun hukum membaca Al-Qur'an dengan memakai aturan-aturan tajwid adalah fardu 'ain atau merupakan kewajiban pribadi. Membaca Al-Qur'an sebagai sebuah ibadah haruslah dilaksanakan sesuai dengan ketentuan. Ketentuan itulah yang terangkum dalam ilmu tajwid. Dengan demikian memakai Ilmu Tajwid dalam membaca Al-Qur'an hukumnya wajib bagi setiap orang, dan tidak bisa diwakili oleh orang lain (Acep Lim Abdurohim : 6).

Dari kajian teori diatas dapat ditarik kesimpulan bahwasannya media pembelajaran akan sangat membantu keefektifan proses pembelajaran, serta dapat membangkitkan motivasi dan minat siswa, media pengajaran juga dapat membantu siswa meningkatkan pemahaman. Melalui penggunaan media, pembelajaran dapat lebih bermakna, yakni media pembelajaran bukan hanya dapat meningkatkan pemahaman informasi berupa data dan fakta sebagai pengembangan aspek kognitif tahap rendah, akan tetapi dapat meningkatkan kemampuan siswa untuk menganalisis dan menciptakan sebagai aspek kognitif tahap tinggi (Azhar Arsyad : 15-16).

Dalam proses pembelajaran media memiliki kontribusi dalam meningkatkan mutu dan kualitas pengajaran. Kehadiran media tidak saja membantu pengajar dalam penyampaian materi ajarnya, tetapi bagi segala 
jenis media, baik yang canggih dan mahal ataupun media yang sederhana dan murah (Hamzah B. Uno, 116).

Kondisi yang diharapkan akan dapat tercapai dengan menerapkan beberapa metode diantaranya:

1) Melakukan pendekatan langsung dengan cara observasi dan wawancara guru di MI NU Raudlatul Wildan. Diharapkan dari kegiatan ini dapat diketahui potensi, kekurangan dan kendala yang dihadapi oleh Guru dalam mengembangkan media pembelajaran. Sehingga nantinya akan dapat dipetakan dan ditemukan solusi yang tepat untuk menyelesaikan problem tersebut.

2) Melakukan tahapan persiapan perencanaan program-program kegiatan berdasarkan permasalahan dan kendala yang ditemui, sehingga ada solusi untuk penyelesain masalah yang ada. Beberapa persiapan yang perlu dilakukan diantaranya adalah: melakukan survei lokasi kegiatan, pembuatan proposal dan mengurus semua hal-hal administratif pada instansi yang dilibatkan, mengadakan kerjasama dengan ahli dibidang pengembangan media pembelajaran, pembuatan modul oleh pembicara.

3) Pelaksanaan program dengan cara memberikan pelatihan mengenai pengembangan media pembelajaran ilmu tajwid agar para guru dapat memanfaatkan penggunaan media pembelajaran secara efektif.

4) Mengadakan evaluasi program yang telah dijalankan. Untuk mengetahui sejauh mana program pelatihan ini dapat berdampak positif terhadap guru, maka perlu dilakukan evaluasi. Sebagai alat ukur keberhasilan, akan diberikan questionnaire yang berisi seputar kegiatan pelatihan pengembangan media pembelajaran tajwid.

5) Pembuatan laporan hasil kegiatan.

Guru-guru di MI NU Raudlatul Wildan dituntut bisa mengembangkan media pembelajaran di MI karena guru harus kreatif dalam mengembangkan media pembelajaran supaya pembelajaran berlangsung menyenangkan.

Guru-guru merasa apa yang mereka sampaikan monoton, sehingga menerima dengan senang hati saat kami datang ke madrasah, mereka sangat antusias saat kami menjelaskan tentang media. Guru yang lain pun merasa 
bahwa pelatihan ini sangat bermanfaat untuk menambah pengetahuan mereka dalam membuat media pembelajaran. Media yang dibuat menjadi bahan inspirasi mereka dalam pembelajaran apapun.

Problem guru dalam memanfaatkan media yaitu kurang termotivasi dan kurangnya waktu bagi mereka untuk mempersiapkan media pembelajaran sehingga berpengaruh pada rendahnya minat belajar siswa karena media yang diguanakan monoton bahkan guru tanpa menggunakan media saat mengajar. Pelatihan ini juga bertujuan untuk menumbuhkan motivasi guru dalam membuat media pembelajaran.

Penggunaan whiteboard dan handbook dalam pembelajaran ilmu tajwid memang sudah menjadi hal yang biasa. Mayoritas guru sudah mahir menggunakannya dan mengkolaborasikannya dengan penggunaan media yang didapat dari LKS. Guru beranggapan bahwa penggunaan whiteboard dan handbook merupakan media yang sangat tepat untuk proses pembelajaran ilmu tajwid. Pembelajaran tajwid, sebagaimana materi pembelajaran yang lain, memerlukan media inovatif untuk mencapai hasil belajar yang optimal. Ilmu tajwid merupakan materi yang rumit dan sulit, jadi harus terus dikenal sejak dini dengan beragam media.

Guru yang mengajar ilmu tajwid belum mampu mengoptimalkan kreativitas sebagai pendukung proses belajar dan pembelajaran. Dalam proses belajar dan pembelajaran masih digunakan media pembelajaran yang konvensional seperti whiteboard maupun buku pegangan guru. Media-media pembelajaran berupa whiteboard maupun buku pegangan guru terkesan monoton dan membosankan. Dengan memanfaatkan flipchart dan kartu kwartet tajwid, sebenarnya seorang Guru dapat membuat media pembelajaran yang atraktif dan menarik.

Guru beranggapan untuk membuat sebuah media pembelajaran yang kreatif akan menghabiskan waktu. Mereka beranggapan harus menghabiskan banyak waktu menjadi ketakutan tersendiri bagi mereka untuk mengembangkan media pembelajaran yang kreatif dan menarik. Hal ini menyebabkan keengganan untuk belajar lebih jauh tentang pengembangan media pembelajaran. 
Berdasarkan beberapa uraian diatas dapat diketahui bahwa kondisi dan permasalahan yang ada di madrasah adalah: 1) Guru yang mengajar tajwid memiliki pemahaman yang sempit tentang media pembelajaran, baik itu jenisnya, ruang lingkupnya maupun penggunaannya. 2) Belum optimalnya penggunaan peralatan yang menarik. 3) Guru merasa mempunyai kekurangan dalam skill pembuatan media, sehingga tidak ada semangat untuk mengembangkan media pembelajaran tajwid.

Sebelum melakukan pendampingan tentunya tahap persiapan sangat diperlukan agar apa yang pendamping tuju dapat tercapai dengan maksimal. Berikut persiapan yang perlu pendamping lakukan sebelum melakukan pendampingan di MI NU Raudlatul Wildan :

1) Melakukan observasi awal sebelum dilakukannya pendampingan. Observasi awal dilakukan guna mengetahui kondisi Madrasah serta lingkungan dan kelas yang akan diadikan sebagai objek pendampingan.

2) Menyiapkan perlengkapan dan peralatan yang sekiranya dibutuhkan ketika pendampingan berlangsung, salah satunya yaitu media pembelajaran tajwid science garden.

3) Merencanakan kegiatan apa saja yang akan dilakukan selama berada di kelas pendampingan supaya pendampingan berjalan dengan lancar sesuai dengan yang diharapkan.

4) Menyusun tes untuk pendampingan, tes dalam pendampingan ini yaitu berupa soal pertanyaan berupa pilihan ganda. Dimana item soalnya berupa pilihan ganda. Tentunya sebelum soal ini dikerjakan oleh kelas eksperimen dan kelas kontrol harus diujicobakan terlebih dahulu.

5) Pendamping menjelaskan isi materi pembelajaran (hukum bacaan nun mati) dengan menggunakan media tajwid science garden.

6) Guru memperhatikan pendamping yang sedang menjelaskan materi di depan kelas.

7) Pendamping menggunakan metode tanya jawab sebagai variasi kegiatan pembelajaran selain menggunakan metode ceramah.

8) Pendamping juga menggunakan media pembelajaran tajwid science garden sebagai permainan, yaitu dengan membagikan bunga huruf hijaiyah kepada peserta didik yang telah dipilih secara acak kemudian 
peserta didik disuruh untuk mengklasifikan huruf-huruf yang didapat sesuai dengan hukum bacaannya, dengan menempelkan huruf tersebut ke ranting pohon yang telah disediakan.

9) Pendamping mengoreksi dan memberi penguatan jawaban guru.

10) Pendamping meminta guru untuk mengerjakan soal tes. Soal tes dikerjakan pada pertemuan ke-4. Soal tes dikerjakan secara mandiri tidak boleh saling menyontek, atau membocorkan jawaban kepada peserta didik lainnya.

11) Pendamping menutup pembelajaran.

Proses pembelajaran yang digunakan pada kelas kontrol yaitu dengan menggunakan metode seperti biasanya yaitu metode ceramah dan tanya jawab saja. Dalam proses pembelajaran ini guru menjelaskan materi hukum bacaan tajwid (hukum bacaan nun mati) dan memberikan kesempatan bagi peserta didik untuk bertanya dan mencatat materi yang sekiranya perlu untuk dicatat. Dalam kegiatan pembelajaran peserta didik hanya mendengarkan guru menjelaskan saja dan bertanya apa yang belum pahami. Pada kelas kontrol ini tidak digunakan media pembelajaran tajwid science garden.

Selanjutnya pendamping memberikan soal tes yang harus dikerjakan oleh kelas kontrol, yaitu mengenai materi hukum bacaan tajwid (hukum bacaan nun mati) pada mata pelajaran Al-Qur'an Hadits. Proses kegiatan belajar mengajar hanya berpusat pada guru dan tidak ada media pembelajaran yang digunakan kecuali buku dan papan tulis. Di kelas kontrol pun respon siswa berbeda dengan kelas eksperimen. Di kelas kontrol siswa yang merespon atau yang menanggapi dan memberi pertanyaan hanya sedikit sehingga terlihat kurang antusias dalam mengikuti proses kegiatan belajar mengajar.

Soal tes yang dikerjakan oleh masing-masing peserta didik digunakan untuk mengetahui seberapa jauh pemahaman guru pada materi hukum bacaan tajwid (hukum bacaan nun mati). Sedangkan pada kelas eksperimen menggunakan media pembelajaran tajwid science garden yang tentunya dikolaborasikan dengan metode-metode pembelajaran serta strategi pembelajaran yang dianggap sesuai. 


\section{Faktor Pendukung dan Penghambat}

Setiap media pembelajaran pasti mempunyai kelebihan dan kelemahan. Berikut pendamping akan memaparkan mengenai kelebihan dan kelemahan yang dimiliki oleh medi Tajwid Science Garden:

a) Kelebihan:

1) Dengan menggunakan media ini siswa dapat berperan aktif dalam proses kegiatan belajar mengajar;

2) Pusat perhatian siswa akan terpusat pada media pembelajaran, karena media tersebut merupakan hal baru bagi siswa;

3) Merangsang rasa penasaran siswa ketika proses belajar mengajar berlangsung;

4) Menambah antusiasme siswa;

5) Melatih keberanian siswa untuk maju ke depan kelas.

b) Kelemahan:

1) Karena media tersebut terbuat dari kertas, maka akan mudah robek jika tidak hati-hati;

2) Membutuhkan waktu yang lama, karena media ini digunakan sebagai alat evaluasi.

3) Terlalu repot menggunakan media pembelajaran tajwid science garden ini, karena setelah digunakan harus dibongkar pasang kembali.

4) Media yang digunakan pendamping ini hanya bisa digunakan untuk materi hukum bacaan nun mati saja, jika ingin menggunakan media pembelajaran tajwid science garden pada materi tajwid yang lain harus membuat lagi media serupa.

Proses kegiatan belajar mengajar seharusnya berjalan dengan efektif dan efisien, supaya tujuan pendidikan yang telah dirancang dapat tercapai. Pembelajaran dianggap efektif apabila nilai yang dicapai siswa memenuhi batas minimal kompetensi yang telah dirumuskan. Suatu proses belajar mengajar dapat dikatakan berhasil baik, jika kegiatan belajar mengajar tersebut dapat membangkitkan proses belajar.

Proses belajar itu terjadi karena adanya interaksi antara seseorang dengan lingkungannya. Salah satu pertanda bahwa seseorang itu telah belajar adalah adanya perubahan tingkah laku pada diri orang itu yang mungkin disebabkan 
oleh terjadinya perubahan pada tingkat pengetahuan, keterampilan atau sikapnya.

Proses belajar mengajar dapat berhasil dengan baik, jika siswa bisa diajak untuk memanfaatkan semua alat inderanya. Sedangkan guru berupaya untuk menampilkan rangsangan (stimulus) yang dapat di proses dengan berbagai indera. Semakin banyak indera yang digunakan untuk menerima dan mengolah informasi, semakin besar pula kemungkinan informasi tersebut dimengerti dan dapat dipertahankan dalam ingatan. Dengan demikian, siswa diharapkan akan menerima dan menyerap dengan mudah dan baik pesan-pesan dalam materi yang disajikan melalui media yang digunakan oleh seorang guru (Supardi, 2015: 164).

Ilmu Tajwid menjadi salah satu alat bagi kaum muslim untuk dapat membaca al-Qur'an dengan sempurna. Seorang muslim yang mampu menguasai teori-teori dalam ilmu Tajwid dan menerapkannya dalam membaca al-Qur'an akan dapat menghindarkan diri dari dosa akibat kesalahan membaca. Oleh karenanya, perlu upaya sejak dini untuk mengenalkan ilmu tajwid kepada generasi muslim agar kelak mampu berinteraksi dengan al-Qur'an secara optimal.

Beberapa madrasah, terutama di pedesaan, masih melaksanakan pembelajaran tajwid secara lisan, yakni siswa membaca al-Qur'an sementara guru menyimak sambil sesekali membetulkan bacaan yang salah. Ada juga pengajar yang melaksanakan pembelajaran ilmu tajwid secara terpisah dengan menggunakan media whiteboard dan buku pegangan (handbook) tertentu. Namun upaya tersebut dirasa kurang maksimal, karena pihak guru merasa kesulitan menarik perhatian siswa, sementara pihak siswa pun merasa sulit memahami materi tajwid yang dijelaskan guru (Winarsih, $2015: 2$ ).

Selain itu, penggunaan media pembelajaran yang kurang variatif dalam pembelajaran ilmu tajwid menyebabkan siswa merasa jenuh dalam proses belajar mengajar. Hal tersebut berimbas pada tidak terserapnya materi pelajaran secara maksimal (Nana Sudjana dan Ahmad Rivai, 2005).

Madrasah Ibtidaiyah NU Raudlatul Wildan di Desa Ngembalrejo Kudus, menurut observasi dan wawancara dengan guru PAI, juga mengalami problem dalam pelaksanaan pembelajaran ilmu tajwid karena kendala media. Bahkan 
pembelajaran tajwid masuk kegiatan ekstrakurikuler demi mendongkrak pemahaman siswa dan meningkatkan hasil belajar. Namun, media pembelajaran yang masih dominan menggunakan whiteboard maupun buku pegangan guru justru menjadi kendala tersendiri.

Fenomena tersebut mengindikasikan bahwa media menjadi kebutuhan yang bersifat niscaya bagi guru agar dapat meningkatkan kualitas pembelajaran dan mempertingi hasil belajar yang dicapai (Nana Sudjana dan Ahmad Rivai, 2005) karena penelitian menegaskan bahwa media pembelajaran sangat mempermudah guru menyampaikan materi kepada siswa (Ernawati, E, 2014 : 2). Sementara itu, media visual diyakini sangat media ideal karena berpotensi tinggi meningkatkan hasil belajar siswa (Winarsih, P. L. B, 2015: 2).

Media pembelajaran dapat digunakan untuk berbagai ragam tujuan. Fungsi media pengajaran sangatlah besar, karena media pengajaran menentukan berhasil tidaknya proses pengajaran dan merupakan bagian yang terpadu atau tidak dapat dipisahkan dalam sistem pengajaran. Media pengajaran tidak hanya sebagai alat untuk menyampaikan atau mentransfer informasi dan pengetahuan ke otak siswa, akan tetapi lebih dari itu media dapat dijadikan sebagai alat untuk mendorong siswa untuk memperoleh keterampilan-keterampilan, kebiasaan, bakat, minat, serta nilai-nilai yang diinginkan.

Perkembangan ilmu pengetahuan dan teknologi semakin mendorong upaya-upaya pembaharuan dalam pemanfaatan hasil-hasil teknologi dalam proses belajar. Para guru dituntut agar mampu menggunakan alat-alat yang disediakan oleh sekolah, dan tidak menutup kemungkinan alat-alat tersebut sesuai dengan perkembangan dan tuntutan zaman. Guru sekurang-kurangnya dapat menggunakan alat yang murah dan efisien yang meskipun sederhana dan bersahaja tetapi menjadi keharusan dalam upaya mencapai tujuan pengajaran yang diharapkan. Disamping mampu menggunakan alat-alat yang tersedia, guru juga dituntut untuk dapat mengembangkan keterampilan membuat media pengajaran yang akan digunakannya apabila media tersebut belum tersedia. Untuk itu guru harus memiliki pengetahuan dan pemahaman yang cukup tentang media pengajaran (Azhar Arsyad, 2006 : 1-2).

Madrasah, sebagai salah satu basis pembelajaran al-Qur'an, harus segera berbenah dan meningkatkan kualitas pembelajaran tajwid dengan 
mengembangkan kualitas media pembelajarannya. Pengembangan media pembelajaran tajwid berupa kartu, yakni flipchart dan kartu kwartet tajwid. Media kartu dengan segala kelebihan dan kekurangannya harus dikembangkan dan dimodifikasi bahan, bentuk maupun designnya agar lebih menarik dan menyenangkan.

Hasil pengabdian di MI NU Raudlatul Wildan ternyata dengan adanya pelatihan ini guru dapat mengajar sesuai harapan siswa. Melihat kondisi dan fakta di atas diperlukan upaya pengembangan kualitas media pembelajaran ilmu tajwid, khususnya hukum bacaan tajwid bagi guru-guru di Madrasah Ibtidaiyah NU Raudlatul Wildan desa Ngembalrejo Kudus.

\section{Simpulan}

Berdasarkan permasalahan, hasil analisis dan pembahasan yang telah dipaparkan, maka dapat disimpulkan: Pelatihan pembuatan media pembelajaran tajwid science garden efektif dalam meningkatkan pemahaman materi hukum bacaan tajwid pada mata pelajaran Al-Qur'an hadits. Sebaiknya guru lebih memperhatikan penggunaan media pembelajaran hurusnya pada materi hukum bacaan tajwid dalam mata pelajaran Al-Qur'an hadits ketika proses belajar mengajar berlangsung, supaya merangsang rasa keingintahuan siswa, serta siswa tidak merasa jenuh dan bosan dengan proses belajar yang cenderung monoton.

Media pembelajaran tajwid science garden merupakan salah satu alternatif media pembelajaran yang dapat digunakan pada mata pelajaran AlQur'an hadits pada materi hukum bacaan tajwid yaitu hukum bacaan nun mati. Media pembelajaran tajwid science garden membutuhkan waktu ekstra dalam persiapan, sehingga sebelum memulai pembelajaran sebaiknya guru telah mempersiapkannya dengan matang. Karena media ini digunakan oleh guru sepanjang pembelajaran berlangsung.

Sebelum pelaksanaan pembelajaran menggunakan media ini, guru harus dapat mempersiapkan komponen pendukung seperti rencana pembelajaran yang lebih sistematis, dan juga mempersiapkan media itu sendiri. 


\section{Daftar Pustaka}

Abdurrohim. 2003. Acep Lim. Pedoman Ilmu Tajwid Lengkap, CV. Penerbit Diponegoro, Bandung.

Ahmadi, Rulam. 2014. Pengantar Pendidikan, Ar-Ruzz Media, Yogyakarta.

Al-Mujahid, Ahmad Thoha Husein. 2011. Ilmu Tajwid (Pegangan para Pengajar AlQur'an dan Aktifis Dakwah), Darus Sunnah Press, Jakarta.

Anderson, Lorin W. 2015. Kerangka Landasan Untuk Pembelajaran, Pengajaran, dan Asesmen, Pustaka Belajar, Yogyakarta.

Annuri, Ahmad. 2010. Panduan Tahsin Tilawah Al-Qur'an dan Pembahasan Ilmu Tajwid, Pustaka Al-Kautsar, Jakarta.

Arifin, Zainal. 2012. Evaluasi Pembelajaran, Direktorat Jenderal Pendidikan Islam Kementrian Agama RI, Jakarta.

Arsyad, Azhar. 2006. Media Pembelajaran. Jakarta: Rajawali Pers.

Hamdayana, Jumanta. 2016. Metodologi Pengajaran, Bumi Akasara, Jakarta.

Hasanah, Iswatun. 2010. "Rancang Bangun Media Pembelajaran Tajwid Berbasis Multimedia", Jurnal Dasi, Vol. 11. No. 4 Desember.

Rohani, Ahmad. 1997. Media Intruksional Edukatif, PT Rineka Cipta, Jakarta.

Sugiyono. 2005. Memahami Pendampingan Kualitatif, Alfabeta, Bandung.

Indriana, Dina. 2011. Ragam Alat Bantu Media Pengajaran, DIVA Press, Jogjakarta.

Tatang S. 2015. Manajemen Pendidikan Berbasis Sekolah, Pustaka Setia, Bandung.

Hujair AH Sanaky. 2013. Media Pembelajaran Interaktif-Inovatif, Kaukaba Dipantara, Yogyakarta.

Hamzah B. Uno. 2009. Profesi Kependidikan, Bumi Aksara, Jakarta.

Kadar M. Yusuf. 2013. Tafsir Tarbawi, AMZAH, Jakarta.

Harjanto, 2010. Perencanaan Pendidikan, Rineka Cipta, Jakarta.

Sanjaya, Wina. 2014. Media Komunikasi Pembelajaran, Prenada Media Group, Jakarta.

Sanjaya, Wina. 2011. Kurikulum dan Pembelajaran: Teori dan Praktik Pengembangan Kurikulum Tingkat Satuan Pendidikan, Kencana Prenada Media Group, Jakarta.

Sadiman, Arief S. 2012. Media Pendidikan, PT Raja Grafindo Persada, Jakarta. 
Nana Sudjana dan Ahmad Rivai. 2009. Media Pengajaran, Sinar Baru Algensindo, Bandung.

Wowo Sunarya Kuswana, Taksonomi Kognitif, PT Remaja Rosdakarya, Bandung, 2012.

S. Nasution, Berbagai Pendekatan dalam proses belajar dan mengajar, Bumi Aksara, Jakarta, T.th.. 